\title{
Performance Analysis and Quality Evaluation of Wheat Storage in Horizontal Silo Bags
}

\author{
Mohamed M. El-Kholy and Reham M. Kamel \\ Agricultural Engineering Research Institute, Agricultural Research Center, Giza, Egypt \\ Correspondence should be addressed to Reham M. Kamel; rehamkamel8541@gmail.com
}

Received 21 June 2021; Revised 22 August 2021; Accepted 23 August 2021; Published 6 September 2021

Academic Editor: Giorgia Spigno

Copyright (c) 2021 Mohamed M. El-Kholy and Reham M. Kamel. This is an open access article distributed under the Creative Commons Attribution License, which permits unrestricted use, distribution, and reproduction in any medium, provided the original work is properly cited.

\begin{abstract}
Wheat still suffers from the problem of traditional storage methods, limited storage capacity, and a high percentage of losses in terms of quantity and quality. Hermetic silo bags are economical and alternative technique to the traditional storage methods. Ten horizontal plastic silos with the capacity of 200 tons/silo were tested and evaluated for eight months of wheat storage. The evaluations included grain bulk temperature, $\mathrm{CO}_{2}$ concentration, fungal and microbial count, insect count, grain moisture content, 1000-grain weight, falling number, and protein content. The results showed that the stored wheat quality was maintained without any significant difference during the storage period in terms of 1000-grain weight, grain moisture content, and falling number, while there were slight changes in protein content and kernel hardness with a decrease of $5.5 \%$ and $4.6 \%$ at the end of the storage period. There were no statistically significant differences at the sampling location along the length of the storage silos, which confirms the homogeneity of the internal conditions of the examined silo. The grain bulk temperature inside the silos was always lower than the surrounding ambient air temperature. The higher concentration of carbon dioxide inside the silos during the storage period led to a decrease in fungal and microbial count and the presence of dead insects at the end of the storage period.
\end{abstract}

\section{Introduction}

Wheat (Triticum aestivum vulgare L.) is one of the most important strategic crops in the world [1]. The available storage capacity in most countries cultivating wheat is currently insecure and insufficient for crop storage capacity [2].

Documented grain postharvest loss estimates worldwide differ by grain and by region, but typically ranged from 2 to $10 \%$ [3]. The total wheat postharvest losses approached $4.32 \%$ while storage losses reached the maximum of $(41.7 \%$ of the total) among all postharvest operations $[4,5]$. Qualitative losses such as insect or heat damaged kernels, insectinfested, and microbial contaminated grains unfit for consumption or sale. Developing new tools to reduce the amount of grain losses after harvest, especially at the storage stage, is an important strategy to fight hunger and poverty and increase global food and nutrition security.

Various methods are used for storing wheat such as jute or burlap bags, metal silos, bulk storage in rooms, and open- air door called (Shona) [6]. During storage, the grains are exposed to serious problems in composition and quality, especially for the traditional and uncontrolled storage methods [7]. Quality losses of wheat due to improper storage method and conditions exceed $6.6 \%$ for storage in jute bags under outdoor storage conditions, and these losses can be reduced up to $2 \%$ if stored in metal silos [8]. However, the current metal silo does not provide complete protection for safe storage against insect infestation and mould. In addition, they often suffer temperature fluctuations, grains lumping due to moisture condensation on the inner wall of the silos, and also high energy consumption due to mechanical aeration process [9].

Silo bags are a relatively new form of crop storage in many countries that are used to store different types of grains such as wheat, barley, corn, soybean, sunflower, canola, and many other crops [10-14]. Storage of dry wheat grains in an economical hermetic silo bag is an alternative technique to traditional storage methods and/or metal silos. 
The main advantage of silo bags storage is to reduce transportation costs during harvesting season from production fields to storage sites because it can be placed in any part of the farm [15]. This technique allows the modified atmosphere storage system results from respiration of grains and microorganisms to increase $\mathrm{CO}_{2}$ and decrease $\mathrm{O}_{2}$ concentration (less than 10\%). This condition reflects in reduction of biological activities of the microorganisms inside the bags and thus creates an unfavorable modified atmosphere for insects and moulds $[10,15,16]$.

Previous studies of wheat storage in silo bags included mathematical modeling and determination the change in concentration $\mathrm{CO}_{2}$ in silo bags carrying wheat in Argentina [17]. Development of insect species is in wheat silo bags under tropical and moderate weather conditions [18]. Analysis heat and moisture transfer inside the silo bags are filled with wheat by [19]. Simulation of the change in gas concentration is as related to respiration rate and permeability of the plastic materials of bags under Argentina condition [20].

In general, this system has been successfully certified for grain storage in Argentina [18-21], Australia [22, 23], Canada [14], and other countries. However, Egyptian conditions (as representative location for the African areas in terms of weather, economic, and social conditions) differ significantly from other sites where this technology has been applied.

The main objective of the current study is to test and evaluate the hermetic storage technology of wheat in horizontal silo bags under Egyptian conditions in order to solve the problem of limited storage capacity high storage losses in quantity and quality and eliminating the need for using the nonhealthy phosphine fumigation. The effect of the wheat storage period (eight months) and sampling location on grain temperature, moisture content, $\mathrm{CO}_{2}$ concentration, fungal and microbial count, and insect count inside ten examined silos with capacity of 200 ton/silo were monitored. The changes in grain quality were also monthly tested and evaluated under the following methodology.

\section{Materials and Methods}

2.1. Preparing Grain Samples. Samples of wheat cultivar (Gimmiza-9) were harvested at a moisture content of $11.86 \%$. w.b. The collected samples were cleaned of foreign, broken, and immature kernels before storage in the examined silo bags.

2.2. Methods. Ten horizontal plastic silo bags with capacity of 200 tons/silo were installed in a wheat storage site at the north of Egypt $\left(31^{\circ} 22^{\prime \prime} \mathrm{N}-31^{\circ} 34^{\prime \prime} \mathrm{E}\right)$ as shown in Figure 1. The silo dimensions were $2.74 \mathrm{~m}$ diameter and $60 \mathrm{~m}$ long with a polyamid film thickness of 230 micron. A white outer layer of the tested silos was assigned to reflect the ultraviolet radiation causing grain heating, and the black inner was used to prevent light transmission to the stored grain. The storage period began from June, 2020 to January, 2021. The specifications of the plastic film used for developing the tested silos are summarized in Table 1.
The grain bagger model Mainero-2230 and grain cart model Cestari-10.000 LXXI were used for charging the grain into the silo bags, and the grain extractor model EA-910 Richiger was used for grain discharging at the end of storage period (see Figure 2). For testing process, three samples were monthly collected at different locations along the length of each silos (front, middle and end of the silo). Three subsamples were also taken from each location at different depths (A-top $=0.2 \mathrm{~m}$ depth, B-middle $=1.37 \mathrm{~m}$ depth, and C-bottom $=2.54 \mathrm{~m}$ depth). The sampling process was conducted by penetrating the surface of plastic film using a steel probe of $1.52 \mathrm{~m}$ collecting $1.5 \mathrm{~kg}$ at each testing point/silo. The points of sampling locations were closed using a special plastic tape to keep precise sealing of silos.

\subsection{Equipment and Measuring Procedures}

2.3.1. Ambient Air Temperature and Relative Humidity. A temperature meter (Model Kaye Dig. 14) with thermal sensors was used to measure the ambient air temperature at different location of storage site, and a relative humidity meter (Model Ex-Tech) was used for measuring are the relative humidity at adjacent point of temperature measurement.

2.3.2. Grain Bulk Temperature. Grain bulk temperature inside the examined silos was measured at different locations of each silo using a temperature meter probe and recorded (Lutron, Model MS-7011).

2.3.3. Grain Moisture Content. The wheat moisture content was determined using the standard method [24]. 10 grams of wheat grain was placed in an electric air oven at $130^{\circ} \mathrm{C}$ for $16 \mathrm{~h}$, and then they were kept in a desecrator under room temperature for $15 \mathrm{~min}$ and weighted by a digital balance with accuracy $0.001 \mathrm{~g}$.

2.3.4. 1000-Grain Weight. 1000 grains were counted and then weighted using a precision electronic scale (accuracy $0.001 \mathrm{~g}$ ).

2.3.5. Carbon Dioxide Concentration. $\mathrm{CO}_{2}$ concentration was monitored monthly at different locations of each silo by $\mathrm{O}_{2}$ and $\mathrm{CO}_{2}$ Analyzer (VIGAS, Model Box-121).

2.3.6. Fungal and Microbial Count. Grain samples were monthly collected from different locations of each silo to determine mold prevalence (cfu/g of grains), using the procedure described by [25]. $25 \mathrm{~g}$ of representative samples were soaked in $250 \mathrm{ml}$ of sterile peptone $(0.1 \%)$ water for $30 \mathrm{~min}$ before digestion for $2 \mathrm{~min}$. $1 \mathrm{ml}$ of the sample, serially diluted in $9 \mathrm{ml}$ of peptone water and a $100 \mu \mathrm{l}$ sample from the serial dilution, was drop plated on dichloron glycerol-18 (DG-18) agar medium (Oxoid chemicals, Hampshire, UK) and incubated at $35^{\circ} \mathrm{C}$ for $4-5$ days. After incubation, the former colonies were recorded (cfu/g).

2.3.7. Insect Count. Grain samples from different locations of the tested silos were sieved, and the insect pests were identified according to [24].

2.3.8. Protein Content. The percentage of the crude protein was measured as $\mathrm{N}$ concentration and converted to protein 


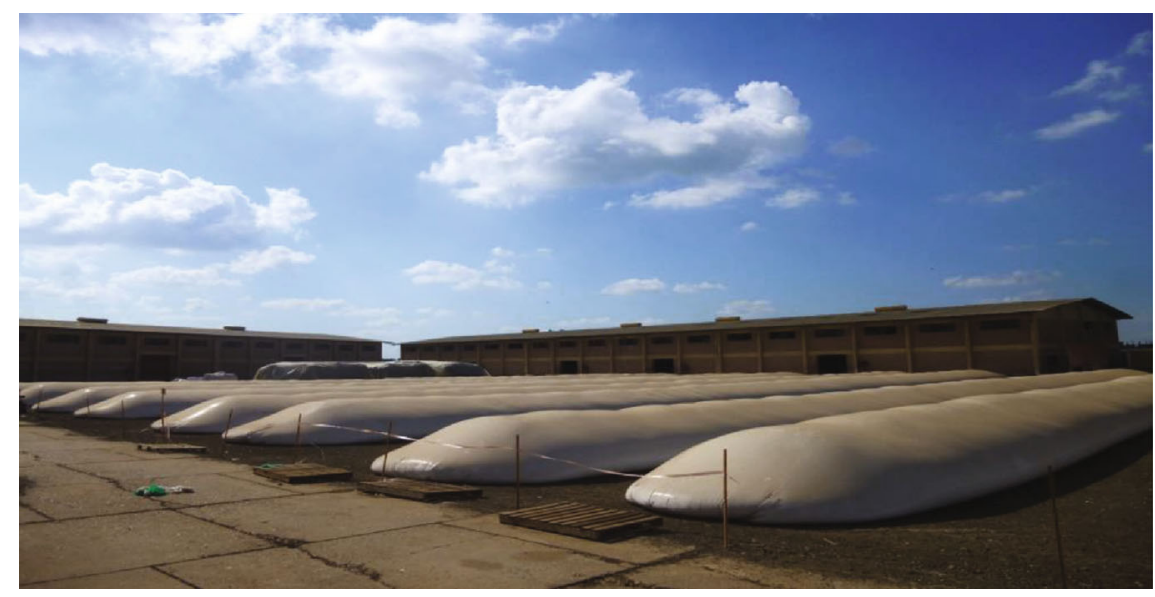

FIgURe 1: Photo for the tested horizontal silo bags (capacity 200 ton/silo).

TABLE 1: Specifications of the tested plastic silo film.

\begin{tabular}{|c|c|c|c|c|c|}
\hline Property & Unit & Method & Max. & $\begin{array}{l}\text { Value } \\
\text { Min. }\end{array}$ & Mean \\
\hline Average thickness & $\mu \mathrm{m}$ & \multirow{2}{*}{ DIN 53370} & 251 & 243 & 250 \\
\hline 2 SEGMA thickness tolerance & $\%$ & & 5.6 & 3.8 & 4.7 \\
\hline Width & $\mathrm{mm}$ & Internal & 442 & 442 & 442 \\
\hline \multicolumn{6}{|l|}{ Coefficient of friction } \\
\hline Out/out & & \multirow{2}{*}{ ASTM D 1894} & 0.40 & 0.36 & 0.38 \\
\hline In/in & - & & 0.20 & 0.18 & 0.19 \\
\hline NTR/M & & ISO 8295 & - & - & - \\
\hline Surface tension & Dyn/CM & DNI ISO 8296 & - & 38 & - \\
\hline Tensile strength at break MD & Mpa & \multirow{10}{*}{ ASTM D882 } & 50.2 & 42.2 & 46.6 \\
\hline Tensile strength at break TD & Mpa & & 46.1 & 41.2 & 43.4 \\
\hline Tensile strength at yield MD & Mpa & & 19.1 & 15 & 17.3 \\
\hline Tensile strength at yield TD & Mpa & & 21.8 & 20.4 & 21 \\
\hline Elongation at break MD & $\%$ & & 569.4 & 475.7 & 531.7 \\
\hline Elongation at break TD & $\%$ & & 591.6 & 524.5 & 563.2 \\
\hline Elongation at yield MD & $\%$ & & 7.8 & 6.7 & 7.3 \\
\hline Elongation at yield TD & $\%$ & & 8.1 & 7.1 & 7.8 \\
\hline Oxygen permeability & $\mathrm{Cc} / \mathrm{m}^{2} /$ day & & & & $\leq 450$ \\
\hline Water vapor permeability & $\mathrm{g} / \mathrm{m}^{2} /$ day & & & & $\leq 2$ \\
\hline
\end{tabular}

by multiplying this percentage by the nitrogen constant factor. The standard semimicro kijeldahl method was used according to $[14,22,26]$.

2.3.9. Falling Number. Falling number of the flour obtained from stored wheat was determined according to the [17] method. A suspension of flour was prepared by adding $25 \mathrm{ml}$ of distilled water to $7 \mathrm{~g}$ of wheat flour (14\% d.b) in two falling number tubes. The suspension was heated to gelatinize the starch of flour, and time counted in secs to drop down a plunger having definite weight into the gelatinized flour paste was recorded as falling number.
2.3.10. Kernel Hardness. The hardness meter (Model SHIMPO, FGC-50) was used for determination of kernel hardness [27].

2.4. Statistical Analyses. Measuring values of different tested factors were represented as the mean \pm SD (standard deviation) for ten replicates. A one-way or two-way analysis of variance (ANOVA) and the correlation coefficient [28] were conducted by the SPSS 19.0 software, and the least significant difference (LSD) was determined by using multiple range tests. $p$ values less than 0.05 were considered significant. 


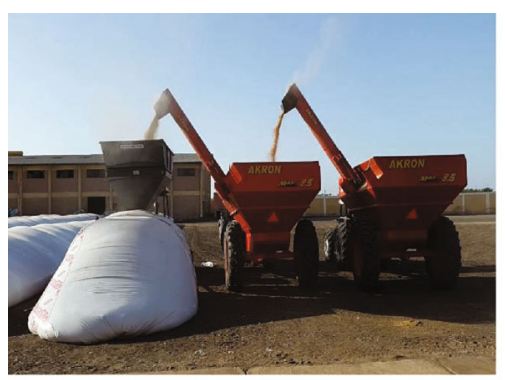

Grain cart model Cestari -10.000 LXXI

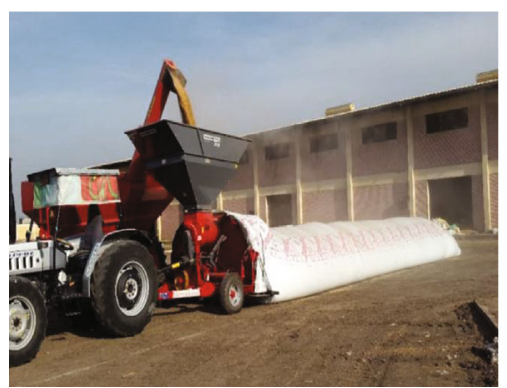

Grain bagger model Mainero -2230

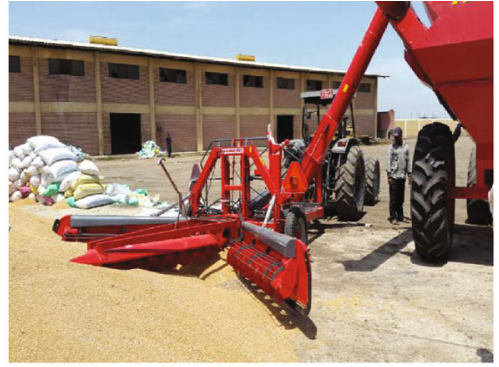

Grain sweeper

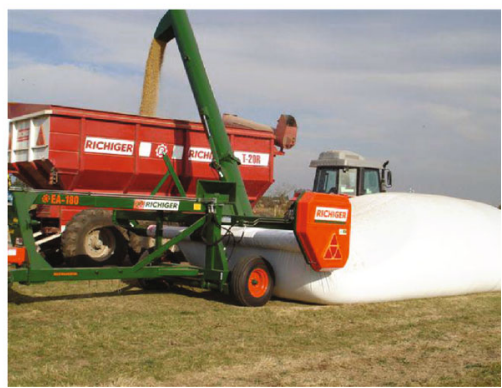

Grain extractor model EA-910 Richiger

FIGURE 2: Machinery used for silo bag processing.

TABle 2: Ambient air temperature $\left({ }^{\circ} \mathrm{C}\right)$, relative humidity $(\%)$, and rainfall $(\mathrm{mm})$ during the storage period (June, 2020-Jan, 2021).

\begin{tabular}{lccccccccc}
\hline & \multicolumn{3}{c}{ Ambient temperature, ${ }^{\circ} \mathrm{C}$} & \multicolumn{2}{c}{ Air relative humidity, } & \multicolumn{3}{c}{ Rainfall, mm } \\
Storage period & $\begin{array}{c}\text { Mean } \pm \text { SD } \\
\left({ }^{\circ} \mathrm{C}\right)\end{array}$ & Maximum & Minimum & $\begin{array}{c}\text { Mean } \pm \text { SD } \\
(\%)\end{array}$ & $\begin{array}{c}\text { Maximum } \\
\text { Minimum }\end{array}$ & $\begin{array}{c}\text { Mean } \pm \text { SD } \\
(\%)\end{array}$ & $\begin{array}{c}\text { Maximum } \\
\text { Minimum }\end{array}$ \\
\hline June, 2020 & $24.87 \pm 5.85$ & 31.60 & 21.00 & $60.50 \pm 20.60$ & 81.40 & 40.20 & $0.00 \pm 0.00$ & 0.00 & 0.00 \\
July, 2020 & $29.17 \pm 4.84$ & 33.60 & 24.00 & $66.00 \pm 17.55$ & 82.70 & 47.70 & $0.00 \pm 0.00$ & 0.00 & 0.00 \\
Aug., 2020 & $28.20 \pm 4.75$ & 32.50 & 23.10 & $68.97 \pm 14.73$ & 83.10 & 53.70 & $0.00 \pm 0.00$ & 0.00 & 0.00 \\
Sept., 2020 & $27.30 \pm 4.95$ & 31.80 & 22.00 & $64.43 \pm 15.63$ & 79.40 & 48.20 & $0.00 \pm 0.00$ & 0.00 & 0.00 \\
Oct., 2020 & $22.50 \pm 4.65$ & 26.50 & 17.40 & $59.40 \pm 15.31$ & 74.30 & 43.70 & $0.00 \pm 0.00$ & 0.00 & 0.00 \\
Nov., 2020 & $21.63 \pm 4.14$ & 25.40 & 17.20 & $66.30 \pm 14.05$ & 78.80 & 51.10 & $1.38 \pm 0.81$ & 2.79 & 0.00 \\
Dec., 2020 & $21.03 \pm 4.44$ & 25.10 & 16.30 & $65.93 \pm 12.23$ & 77.60 & 53.20 & $2.88 \pm 0.53$ & 3.30 & 2.28 \\
Jan., 2021 & $17.23 \pm 4.26$ & 21.30 & 12.80 & $63.04 \pm 15.23$ & 79.30 & 49.10 & $4.32 \pm 1.16$ & 5.33 & 3.06 \\
\hline
\end{tabular}

Results are expressed as means \pm SD $(n=7)$ at 0.05 probability level (one-way ANOVA).

\section{Results and Discussion}

3.1. Ambient Weather Condition of Storage Site. The change in weather condition surrounding the silos during the storage period is presented in Table 2 . The average ambient air temperature ranged from 17.6 to $29.9^{\circ} \mathrm{C}$, while the average relative humidity ranged from 59.9 to $70.1 \%$, and rainfall was about 2.86 from Nov., 2020 to Jan., 2021.

3.2. Grain Bulk Temperature. The change in grain mean bulk temperature usually follows the same trend of the change in ambient air temperature, where the average bulk temperature at the beginning of the storage period was $26.65^{\circ} \mathrm{C}$ (June, 2020) and decreased to $12.43^{\circ} \mathrm{C}$ (Jan., 2021) at the end of storage period (see Table 3 ). According to ANOVA analysis, the grain bulk temperature was significantly different among months $(p<0.05$; LSD0.05 =0.30). Meanwhile, the grain bulk temperature was lower than the daytime ambient temperature due to the effect of white surface layer of silos (Anti-UV), which reflects most of the ultraviolet rays that causing the stored grains to overheat as reported by [29] who mentioned that the outside surface of the metal silo is painted white to reduce the temperature rise of the grains. The results confirm that the temperature of the grains inside the silo is below the permissible limit for insect development and growth. Furthermore, [21, 23] revealed that the optimum temperature for biological activities of storage insects ranges from 26 to $33^{\circ} \mathrm{C}$ and when ambient temperatures are outside this range, these activities are reduced. The lower grain temperature could also be attributed to the lower grain 
TABLE 3: Change in bulk temperature $\left({ }^{\circ} \mathrm{C}\right)$ as related to storage time with regression equation.

\begin{tabular}{lccc}
\hline Storage period & Mean \pm SD $\left({ }^{\circ} \mathrm{C}\right)$ & Maximum & Minimum \\
\hline June, 2020 & $25.65 \pm 0.40 \mathrm{a}$ & 26.33 & 24.73 \\
July, 2020 & $24.51 \pm 0.18 \mathrm{~b}$ & 24.93 & 24.27 \\
Aug., 2020 & $24.62 \pm 0.19 \mathrm{~b}$ & 23.17 & 24.33 \\
Sept., 2020 & $22.99 \pm 0.13 \mathrm{c}$ & 17.57 & 22.70 \\
Oct., 2020 & $17.57 \pm 0.00 \mathrm{~d}$ & 16.53 & 17.57 \\
Nov., 2020 & $15.76 \pm 0.41 \mathrm{e}$ & 14.51 & 15.30 \\
Dec., 2020 & $14.10 \pm 0.43 \mathrm{f}$ & 13.22 & 13.07 \\
Jan., 2021 & $12.43 \pm 0.55 \mathrm{~g}$ & $N=-1.122 T^{5}+7.67 T^{4}-0.00019 T^{3}+0.0205 T^{2}-0.9711 T+40.84$ \\
Regression equation & $r=0.99$ & & 11.75 \\
\end{tabular}

${ }^{*}$ The same lowercase letters mean no significant difference at 0.05 probability level (one-way ANOVA). Results are expressed as means \pm SD $(n=7) .{ }^{*} r$ and S.E are correlation coefficient and standard error estimation of bulk temperature changes, respectively, in wheat during storage time.

respiratory rate, thus avoiding early spoilage during storage period as mentioned by [30] who found that the respiration rate of wheat grain increased after several days when grain temperature increased to 30 and $35^{\circ} \mathrm{C}$.

3.3. Grain Moisture Content. Table 4 shows a slight increase in moisture content of grains ranged from 0.27 to $1.91 \%$ which indicating no reabsorption of moisture from the ambient atmosphere due to the water sealing effect of the plastic film which is characterized by its ability to prevent stored grains from condensed moisture on the surface of silos as well as the rains during winter. These results agreed with the studies conducted by $[6,9,16]$. In general, the storage period, sample location, and interaction between them showed no significant difference by a two-way ANOVA $(p>0.05)$. The results of stability stored in the wheat moisture content also indicate the absence of effective fungal or microbial growth that leads to an increase in grain moisture content [31].

3.4. 1000-Grain Weight. No losses in the grain weight were detected which reflects the absence of any insect growth as shown in Table 4. Analysis of variance indicated no significant differences for storage period, sampling location, and interaction between them $(p>0.05)$ on 1000 -grain weight by two-way ANOVA. These results are in agreement with [32] who stated that moisture content played a significant role in weight loss of grains.

3.5. Carbon Dioxide Concentration. Carbon dioxide concentration also showed significant differences along the storage period $\left(\mathrm{df}=7 ; p<0.05 ; \mathrm{LSD}_{0.05}=0.32\right)$ but the differences was not significant for the sampling location and the interaction between the sampling location and the storage time $(\mathrm{df}=2,14 ; p>0.05)$. From Table 5 , it was clear that the horizontal plastic silos could control the concentration of carbon dioxide gas within the stored grain mass at the safe level for microbes and insect inhibition, meaning that it represents one of the ecosystems as a typical modified atmosphere storage.

The results showed that carbon dioxide levels ranged from 5.39 to $7.27 \%$ during the storage period. In comparison with [20], carbon dioxide remained above $12 \%$ for stored wheat (12-13 w.b) after six months, while it reached $4.6 \%$ in [26] with a difference of $3 \%$ between the summer and winter months. Therefore, it should be noted that the difference in carbon dioxide percentages inside the silos depends on the respiration rate of grains and the level of microorganisms inside the silos in addition to permeability of the plastic film and its ability to maintain the appropriate gaseous balance for the storage process $[16,32,33]$.

3.6. Fungal and Microbial Count. As shown in Figure 3, the average fungal count inside the ten examined silos at the beginning of storage period ranged from 41 to $50 \mathrm{cfu} / \mathrm{g}$, while the average fungal count decreased to a range of 9 to $10 \mathrm{cfu} / \mathrm{g}$ at the end of storage period. This means that the fungal count decreased with the increase of storage period, as this is due to the high percentage of carbon dioxide, especially during the months of November and December. This result is similar to [34] which showed that the fungal growth of stored durum wheat significantly decreased after 5-6 months of storage under 2-5\% $\mathrm{CO}_{2}$ concentration in the silo bag (located in north Italy). Total fungal account also is low compared to $[28,34]$; so, the inability of the existing fungi to produce mycotoxins during the storage period was clean. Fungal counts varied for the storage period $\left(\mathrm{df}=7 ; p<0.05 ; \mathrm{LSD}_{0.05}=5.73\right)$ and for sampling location within the bags $\left(\mathrm{df}=2 ; p<0.05 ; \mathrm{LSD}_{0.05}=3.51\right)$, but the interaction of the storage period and sampling location was not significant $(p>0.05)$ by two-way analysis of variance ANOVA, as mentioned by [28, 33].

Figure 4 presents the change in total microbial count/g of grains as related to storage time. The microbial count ranged from 17190 to $35100 \mathrm{cfu} / \mathrm{g}$ at the beginning of storage period, while the average total microbial count decreased with increasing the storage period and reached the lowest values at the end of the storage period (2022 to $2502 \mathrm{cfu} / \mathrm{g}$ ). The results clarified that total microbial counts varied with the storage period $\left(\mathrm{df}=7 ; p<0.05 ; \mathrm{LSD}_{0.05}=10727.92\right)$ and by sampling location within the bags ( $\mathrm{df}=2 ; p<0.05$; $\left.\operatorname{LSD}_{0.05}=6569.48\right)$, but the interaction of storage period 
TABLE 4: Change in grain moisture content (\% w.b) and 1000-grain weight (g) as related to the storage period and sampling location.

\begin{tabular}{lcccccc}
\hline \multirow{2}{*}{ Storage period, month } & \multicolumn{2}{c}{ Grain moisture content, \% (w.b.) } & \multicolumn{2}{c}{ Sampling location } & \multicolumn{2}{c}{ 1000-grain weight, g } \\
& A & B & C & A & B \\
\hline June-2020 & $11.86 \pm 0.43$ & $11.91 \pm 0.43$ & $11.90 \pm 0.43$ & $40.51 \pm 0.93$ & $40.65 \pm 0.94$ & $40.66 \pm 0.91$ \\
July-2020 & $11.83 \pm 0.41$ & $11.89 \pm 0.43$ & $11.86 \pm 0.42$ & $40.39 \pm 0.79$ & $40.64 \pm 0.93$ & $40.52 \pm 0.79$ \\
Aug.-2020 & $11.85 \pm 0.42$ & $11.86 \pm 0.44$ & $11.90 \pm 0.43$ & $40.50 \pm 0.94$ & $40.65 \pm 0.92$ & $40.67 \pm 0.91$ \\
Sep.-2020 & $11.96 \pm 0.46$ & $11.88 \pm 0.42$ & $11.88 \pm 0.41$ & $40.48 \pm 0.85$ & $40.65 \pm 0.93$ & $40.64 \pm 0.89$ \\
Oct.-2020 & $11.96 \pm 0.47$ & $11.89 \pm 0.42$ & $11.89 \pm 0.43$ & $40.51 \pm 0.92$ & $40.65 \pm 0.96$ & $40.65 \pm 0.89$ \\
Nov.-2020 & $11.87 \pm 0.43$ & $11.92 \pm 0.42$ & $11.90 \pm 0.43$ & $40.54 \pm 0.94$ & $40.67 \pm 0.96$ & $40.66 \pm 0.89$ \\
Dec.-2020 & $12.02 \pm 0.43$ & $12.02 \pm 0.42$ & $12.00 \pm 0.44$ & $40.80 \pm 0.89$ & $40.91 \pm 0.93$ & $40.81 \pm 0.89$ \\
Jan.-2021 & $12.08 \pm 0.43$ & $12.13 \pm 0.44$ & $12.09 \pm 0.44$ & $40.92 \pm 0.92$ & $41.00 \pm 0.94$ & $40.93 \pm 0.92$ \\
\hline
\end{tabular}

Results are expressed as means $\pm \mathrm{SD}(n=14)$ at 0.05 probability level (two-way ANOVA).

TABLE 5: Change in $\mathrm{CO}_{2}$ concentration (\%) inside the tested silos as related to storage period and sampling location.

\begin{tabular}{lcrr}
\hline Storage period, month & \multicolumn{1}{c}{ Sampling location } & C \\
\hline June-2020 & A & $5.64 \pm 0.76 \mathrm{e}$ & $5.63 \pm 0.45 \mathrm{e}$ \\
July-2020 & $5.75 \pm 0.74 \mathrm{de}$ & $5.73 \pm 0.60 \mathrm{de}$ & $5.83 \pm 0.43 \mathrm{de}$ \\
Aug.-2020 & $5.97 \pm 0.81 \mathrm{~d}$ & $5.96 \pm 0.72 \mathrm{de}$ & $6.11 \pm 0.49 \mathrm{~cd}$ \\
Sep.-2020 & $6.39 \pm 0.56 \mathrm{c}$ & $6.37 \pm 0.68 \mathrm{c}$ & $6.49 \pm 0.62 \mathrm{bc}$ \\
Oct.-2020 & $7.01 \pm 0.82 \mathrm{ab}$ & $7.27 \pm 0.51 \mathrm{a}$ & $7.05 \pm 0.57 \mathrm{ab}$ \\
Nov.-2020 & $6.76 \pm 0.89 \mathrm{~b}$ & $6.00 \pm 0.64 \mathrm{~d}$ & $6.71 \pm 0.76 \mathrm{bc}$ \\
Dec.-2020 & $5.94 \pm 0.59 \mathrm{de}$ & $1.92 \pm 0.45 \mathrm{f}$ & $5.97 \pm 0.60 \mathrm{~d}$ \\
Jan.-2021 & $2.09 \pm 0.39 \mathrm{f}$ & & $1.94 \pm 0.50 \mathrm{f}$ \\
Regression equation & & $N=-1.955 T^{4}+7.381 T^{3}-0.0009 T^{2}+0.0508 T+4.646$
\end{tabular}

${ }^{*}$ The same lowercase letters mean no significant difference at 0.05 probability level (two-way ANOVA). Results are expressed as means \pm SD $(n=14) .{ }^{*} r$ and S.E are correlation coefficient and standard error estimation of $\mathrm{CO}_{2}$ changes, respectively, in wheat during storage time.

and sampling location was not significant $(p>0.05)$ as indicated from the two-way ANOVA analysis.

In general, as explained by $[29,35]$, both the number of fungi and total microbial count are affected by the initial state of grains, the percentage of carbon dioxide inside the silo, and the moisture content of grains.

3.7. Insect Count. Insect growth is one of the most important factors affecting the safe storage period and grain quality. Some species of insects such as Oryzaephilusfu surinamesis and Rhyzopertha dominica are able to develop by a percentage of $35 \%$ at low humidity [36]. These insects make holes in the seed and feed on it, as well as help in providing a good environment for fungal and microbial growth as explained by [10].

As shown in Table 6, some insect growths began to appear during the storage month (August) as a result of high ambient temperature and relative humidity with the average count ranged from 0.2 to 0.4 insects $/ \mathrm{kg}$, but most of these insects were not survive due to the high percentage of carbon dioxide inside the silos and the low grain moisture content. The effect of the storage period was significant regarding insect count $\left(\mathrm{df}=7 ; p<0.05 ; \mathrm{LSD}_{0.05}=0.23\right)$ especially between summer and winter seasons. However, sampling location and interaction between the storage period and sampling location were not significant $(p>0.05)$. The obtained results agree with [37], and they confirmed that insect numbers and seed spoilage of wheat were completely controlled at a concentration of $20 \%$ carbon dioxide within two months of the modified atmosphere storage period, and concentrations of 5 and $10 \%$ of carbon dioxide also led to a significant reduction in insect growth and seed spoilage within 6 months compared to ambient condition.

Viable insects did not affect the grains due to their weak activity and their inability to penetrate the surface of the grain, especially the weevil insect $[20,17]$. In general, the stored grains clearly showed no insect infestation during the entire storage period.

3.8. Protein Content and Falling Number. As shown in Table 7, the average percentage of the protein content during the first month of storage was $11.10 \%$ d.b, while it was $10.49 \%$ d.b. at the end of storage period. This means that storage in silo bags led to a slight decrease in protein 


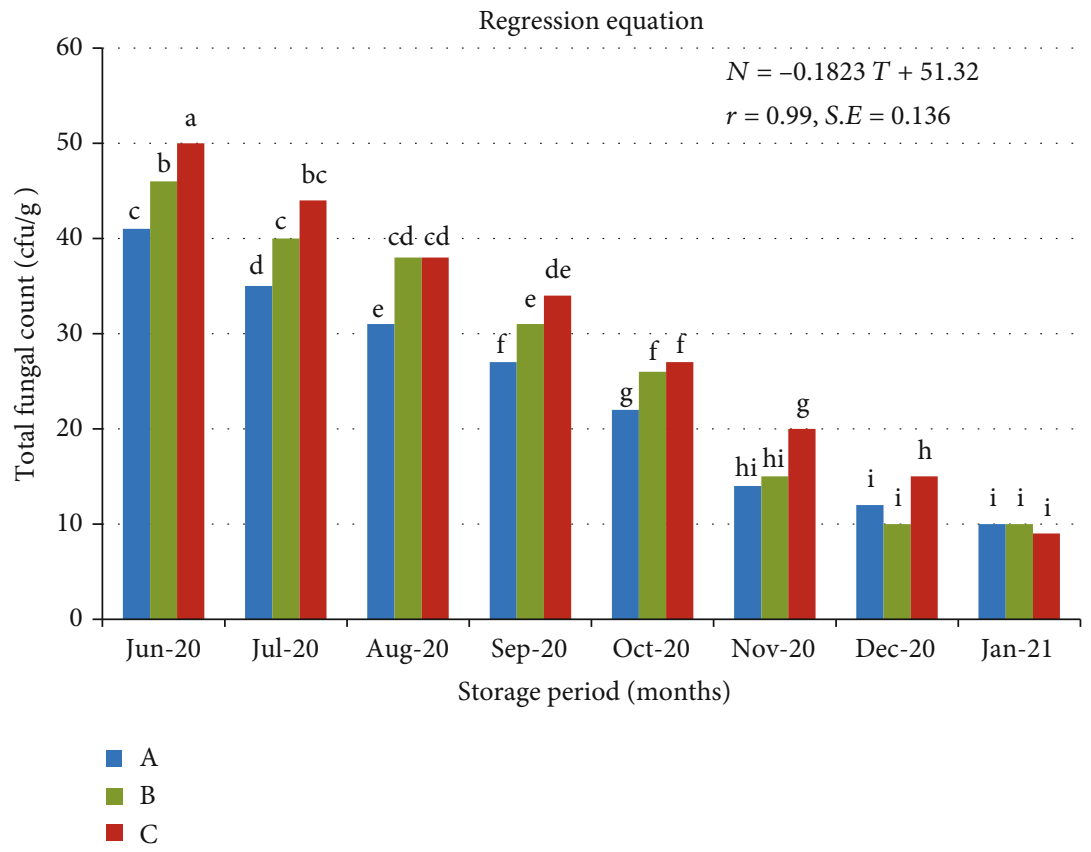

FIgURE 3: Changes in total fungal count inside the examined silos ( $\mathrm{cfu} / \mathrm{g})$ as related to the storage period at different sampling locations $\mathrm{A}, \mathrm{B}$, and $\mathrm{C}$.

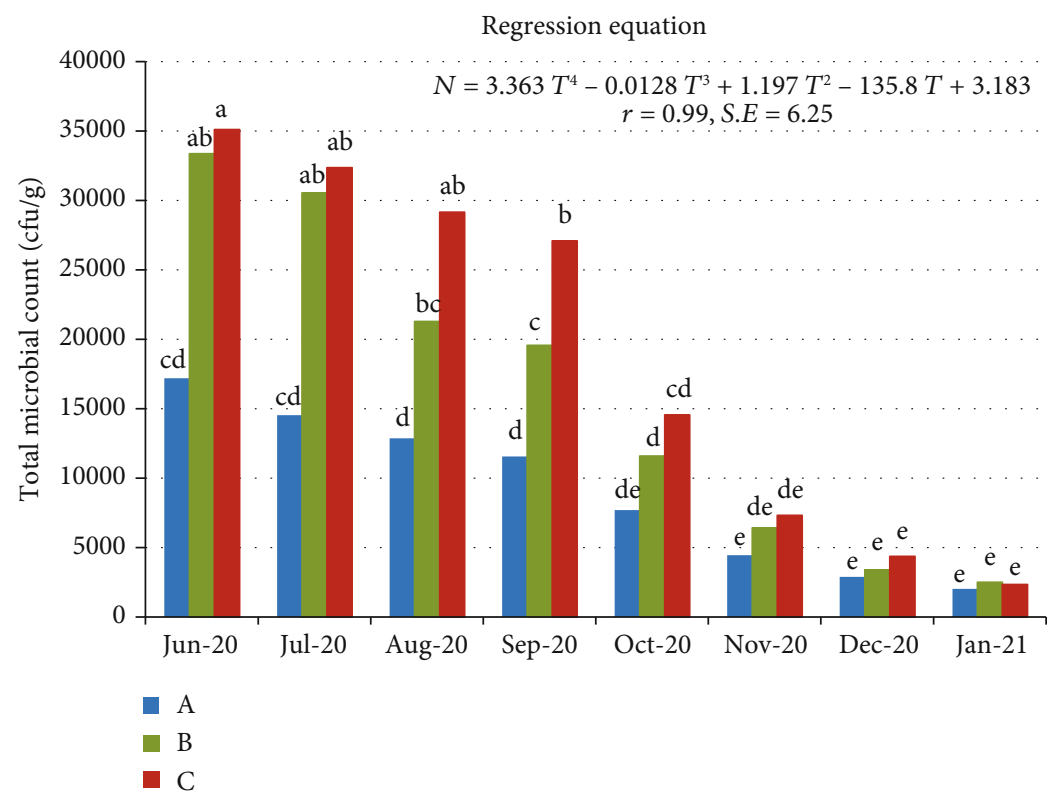

FIGURE 4: Changes in total microbial count inside the storage silos (cfu/g) as related to the storage period at different sampling locations $\mathrm{A}, \mathrm{B}$, and $\mathrm{C}$.

content, equivalent to 5.5\%. One-way ANOVA analysis of variance confirmed that the protein content was significantly different along the storage period $\left(\mathrm{df}=7 ; p<0.05 ; \mathrm{LSD}_{0.05}\right.$ $=0.31$ ). [38] reported that there was a significant decrease in the protein content for stored wheat in silo bags which decreased from $12.6 \%$ to $10.8 \%$ during the storage period.

The average falling number for the stored wheat ranged from $427.60 \mathrm{~s}$ at the first month of storage to $438.30 \mathrm{~s}$ at the end of storage period, which means that it was not affected by the storage period, as illustrated in Table 7 . Falling number was not significant $(p>0.05)$ along the storage months. The falling number was higher than $250 \mathrm{~s}$ which means that the enzyme activity in the tested grain or flour samples is ideal for bread production. The falling number less than $250 \mathrm{~s}$ means increased activity of the amylase hydrolyzate enzyme, which leads to producing flour that is 
TABLE 6: Insect count inside the tested silos (insect $/ \mathrm{kg}$ ).

\begin{tabular}{|c|c|c|c|}
\hline \multirow{2}{*}{ Storage period, month } & \multicolumn{3}{|c|}{ Sampling location } \\
\hline & A & $\mathrm{B}$ & $\mathrm{C}$ \\
\hline June-2020 & $0.00 \pm 0.00 c$ & $0.00 \pm 0.00 c$ & $0.00 \pm 0.00 c$ \\
\hline July-2020 & $0.00 \pm 0.00 c$ & $0.00 \pm 0.00 c$ & $0.00 \pm 0.00 c$ \\
\hline Aug.-2020 & $0.20 \pm 0.04 \mathrm{bc}$ (viable) & $0.40 \pm 0.07 \mathrm{~b}$ (viable) & $0.20 \pm 0.04 \mathrm{bc}($ viable $)$ \\
\hline Sep.-2020 & $0.00 \pm 0.00 c$ & $0.20 \pm 0.04 \mathrm{bc}(\mathrm{dead})$ & $0.00 \pm 0.00 c(\mathrm{dead})$ \\
\hline Oct.-2020 & $0.30 \pm 0.05 b($ dead $)$ & $0.20 \pm 0.04 \mathrm{bc}(\mathrm{dead})$ & $0.00 \pm 0.00 c($ dead $)$ \\
\hline Nov.-2020 & $0.20 \pm 0.04 b c$ & $0.30 \pm 0.05 b$ & $0.30 \pm 0.07 b$ \\
\hline Dec.-2020 & $0.20 \pm 0.06 \mathrm{bc}(\mathrm{dead})$ & $0.04 \pm 0.07 b($ dead $)$ & $0.40 \pm 0.05 b($ dead $)$ \\
\hline Jan.-2021 & $0.00 \pm 0.00 \mathrm{c}$ & $0.70 \pm 0.09 a($ dead $)$ & $0.70 \pm 0.08 \mathrm{a}(\mathrm{dead})$ \\
\hline \multirow{2}{*}{ Regression equation } & \multicolumn{3}{|c|}{$N=-3.429 T^{7}+3.443 T^{6}-1.423 T^{5}+3.109 T^{4}-0.00038 T^{3}+0.0261 T^{2}-0.8902 T+11.33$} \\
\hline & \multicolumn{2}{|l|}{$r=0.99$} & \\
\hline
\end{tabular}

${ }^{*}$ The same lowercase letters mean no significant difference at 0.05 probability level (two-way ANOVA). Results are expressed as means \pm SD $(n=14) .{ }^{*} r$ and S.E are correlation coefficient and standard error estimation of insect count changes, respectively, in wheat during storage time.

TABle 7: Protein content inside silos (\% d.b) and falling number (s) as related to storage period.

\begin{tabular}{|c|c|c|c|c|c|c|}
\hline \multirow{2}{*}{ Storage period, month } & \multicolumn{3}{|c|}{ Protein content, \% d.b } & \multicolumn{3}{|c|}{ Falling number, s } \\
\hline & Mean \pm SD & Maximum & Minimum & Mean \pm SD & Maximum & Minimum \\
\hline June-2020 & $11.10 \pm 0.26 \mathrm{a}$ & 10.66 & 11.60 & $427.60 \pm 25.05$ & 385.00 & 464.00 \\
\hline July-2020 & $10.85 \pm 0.36 \mathrm{ab}$ & 10.30 & 11.35 & $429.60 \pm 20.86$ & 395.00 & 460.00 \\
\hline Aug.-2020 & $10.63 \pm 0.39 \mathrm{~b}$ & 10.00 & 11.20 & $403.90 \pm 43.00$ & 320.00 & 455.00 \\
\hline Sep.-2020 & $10.65 \pm 0.37 b$ & 10.24 & 11.40 & $411.80 \pm 50.80$ & 330.00 & 464.00 \\
\hline Oct.-2020 & $10.64 \pm 0.37 \mathrm{~b}$ & 10.25 & 11.51 & $423.00 \pm 26.69$ & 380.00 & 470.00 \\
\hline Nov.-2020 & $10.73 \pm 0.31 \mathrm{~b}$ & 10.19 & 11.31 & $445.30 \pm 36.28$ & 398.00 & 490.00 \\
\hline Dec.-2020 & $10.55 \pm 0.40 \mathrm{~b}$ & 10.00 & 11.00 & $435.10 \pm 49.70$ & 339.00 & 486.00 \\
\hline Jan.-2021 & $10.49 \pm 0.38 b$ & 9.73 & 11.17 & $438.30 \pm 28.97$ & 396.00 & 495.00 \\
\hline \multicolumn{7}{|c|}{$\begin{array}{c}N=3.62 T^{6}-2.381 T^{5}+5.632 T^{4}-5.944 T^{3}+ \\
0.00033 T^{2}-0.0185 T+11.48\end{array}$} \\
\hline & $r=0.98$ & \multicolumn{2}{|c|}{$\mathrm{S} . \mathrm{E}=0.004$} & & & \\
\hline
\end{tabular}

${ }^{*}$ The same lowercase letters mean no significant difference at 0.05 probability level (one-way ANOVA). Results are expressed as means \pm SD $(n=7) .{ }^{*} r$ and S.E are correlation coefficient and standard error estimation of protein changes, respectively, in wheat during storage time.

TABLE 8: Changes in kernel hardness $(N)$ inside the silos during the storage period and sampling locations $\mathrm{A}, \mathrm{B}$, and C.

\begin{tabular}{lrrr}
\hline Storage period, month & \multicolumn{1}{c}{ Sampling location } & C \\
\hline June-2020 & $51.25 \pm 2.04 \mathrm{ab}$ & $51.04 \pm 1.94 \mathrm{ab}$ & $51.17 \pm 1.97 \mathrm{ab}$ \\
July-2020 & $51.11 \pm 2.05 \mathrm{ab}$ & $51.39 \pm 1.66 \mathrm{a}$ & $51.40 \pm 1.85 \mathrm{a}$ \\
Aug.-2020 & $50.25 \pm 3.84 \mathrm{ab}$ & $50.20 \pm 3.80 \mathrm{ab}$ & $50.30 \pm 3.92 \mathrm{ab}$ \\
Sep.-2020 & $49.35 \pm 3.57 \mathrm{~b}$ & $49.35 \pm 3.93 \mathrm{~b}$ & $49.55 \pm 3.61 \mathrm{~b}$ \\
Oct.-2020 & $48.55 \pm 4.19 \mathrm{~b}$ & $49.35 \pm 3.93 \mathrm{~b}$ & $49.25 \pm 3.87 \mathrm{~b}$ \\
Nov.-2020 & $49.25 \pm 3.98 \mathrm{~b}$ & $49.20 \pm 3.82 \mathrm{~b}$ & $49.25 \pm 3.87 \mathrm{~b}$ \\
Dec.-2020 & $49.00 \pm 3.85 \mathrm{~b}$ & $49.03 \pm 3.77 \mathrm{~b}$ & $48.97 \pm 3.70 \mathrm{~b}$ \\
Jan.-2021 & $48.88 \pm 3.88 \mathrm{~b}$ & $48.66 \pm 1.76 \mathrm{~b}$ & $48.80 \pm 3.66 \mathrm{~b}$ \\
Regression equation & & $N=-1.941 T^{4}+1.018 T^{3}-0.0017 T^{2}+0.1134 T+46.62$
\end{tabular}

${ }^{*}$ The same lowercase letters mean no significant difference at 0.05 probability level. Results are expressed as means \pm SD $(n=14) .{ }^{*} r$ and $S . E$ are correlation coefficient and standard error estimation of kernel hardness changes, respectively, in wheat during storage time. 
not suitable for bread making [39]. In general, the falling number remained in a good range (250-350) with reference to baking quality [40].

3.9. Kernel Hardness. The average of kernel hardness during the first month of storage ranged from 48.80 to $48.88 \mathrm{~N}$, while it was slightly decreased between 51.04 and $51.17 \mathrm{~N}$ with a decrease equivalent to $4.6 \%$ at the end of storage period as shown in Table 8. From the abovementioned results, the kernel hardness decreased slightly due to the slight increase in the moisture content of grains which causes a decrease in their hardness. Wetting effect of wheat grains on their hardness was studied by [41], and the results showed a significant decrease in grain hardness. The mean difference of hardness differed significantly with the storage period ( $\mathrm{df}=7 ; p<0.05 ; \mathrm{LSD}_{0.05}=1.71$ ) but no significant observed with the sampling location $(p>0.05)$ by two-way ANOVA.

\section{Conclusion}

Storage of freshly harvested wheat grain at the initial moisture content of $11.86 \%$ w.b in horizontal silo bags with capacity of 200 ton/silo for 8 months showed a good quality results of stored grain in terms of relatively stable moisture content and grain weight, lower fungal and microbial count, and minimum insect infestation. A slight reduction in the protein content and kernel hardness was detected while the falling number of the wheat flour was suitable for high baking quality. In general, the silo bag storage method is recommended for application in wheat farms as a solution for limited safe storage capacity with minimum quality and quantity losses.

\section{Data Availability}

The data used to support the findings of this study are included within the article.

\section{Conflicts of Interest}

The authors declare no conflict of interest.

\section{Acknowledgments}

The authors would like to express their great thanks and most appreciation to Academy of Scientific Research and Technology for funding the project under the title of "Technology of wheat storage in medium capacity silos (200) ton" also many thanks are due to the Agricultural Engineering Research Institute, Agricultural Research Center, for their support and providing all the required equipment for conducting the current research work.

\section{References}

[1] S. I. Milad, M. N. El-Banna, M. H. El-Sheikh, and M. E. Ebaid, "Effect of genotypes and medium protocols on callus formation and plant regeneration from mature embryos of Egyptian wheat (Triticum aestivum L.) varieties," The Advanced Journal of Agricultural Research, vol. 18, pp. 874-889, 2013.

[2] FAOSTAT, Food and agriculture Organization of the United Nations, 2020, http://www.fao.org/faostat/en/\#data/QC.

[3] F. Appiah, R. Guisse, and P. K. A. Dartey, "Post harvest losses of rice from harvesting to milling in Ghana," Journal of Stored Products and Postharvest Research, vol. 2, pp. 64-71, 2011.

[4] D. Kumar and P. Kalita, "Reducing postharvest losses during storage of grain crops to strengthen food security in developing countries," Foods, vol. 6, no. 1, pp. 8-22, 2017.

[5] B. K. Bala, M. A. Haque, M. A. Hossain, and S. Majumdar, "Post harvest loss and technical efficiency of rice, wheat and maize production system: assessment and measures for strengthening food security," Final Report CF, vol. 6, 2010.

[6] P. Somavat, H. Huang, S. Kumar et al., "Comparison of hermetic storage of wheat with traditional storage methods in India," Applied Engineering in Agriculture, vol. 33, no. 1, pp. 121-130, 2017.

[7] J. González-torralba, S. Arazuri, C. Jarén, and L. M. Arregui, "Influence of temperature and r.h. during storage on wheat bread making quality," Journal of Stored Products Research, vol. 55, pp. 134-144, 2013.

[8] M. K. Sinha and P. D. Sharma, "Storage performance of wheat in different storage structures," Journal of Applied Biology, vol. 14, pp. 83-85, 2004.

[9] J. Bwambale, O. S. Durodola, and V. Nabunya, "Development and evaluation of an improved maize silo to advance food security in Uganda," Cogent Food \& Agriculture, vol. 6, no. 1, 2020.

[10] S. S. Ahmed, S. Y. Abdel-aziz, and M. H. Naroz, "Efficacy of modified atmospheres enriched with carbon dioxide against different life stages of the spider beetle," Gibbium psylloides (Czenpinski) (Coleoptera: Ptinidae), vol. 11, pp. 66-75, 2018.

[11] R. E. Bartosik, J. C. Rodriguez, H. E. Malinarich, and D. E. Maier, "'Silobag": Evaluation of a new technique for temporary storage of wheat in the field," in Advances in Stored Product Protection: Proceedings of the 8th International Working Conference on Stored Product Protection, pp. 1018-1023, York, England, 2002.

[12] R. E. Bartosik, J. C. Rodriguez, and L. Cardoso, "Storage of corn, wheat, soybean and sunflower in hermetic plastic bags," in Proceedings of the international grain quality and technology congress, pp. 1-13, Chicago, USA, 2008, http://www.inta.gov .ar/balcarce/precop/pubcient/BartosikRStorage.pdf.

[13] D. C. Ochandio, L. M. Cardoso, R. E. Bartosik, D. A. De la Torre, J. C. Rodríguez, and J. Massigoge, "Storage of quality malting barley in hermetic plastic bags," Julius-Kühn-Archiv, vol. 425, pp. 331-331, 2010.

[14] V. Chelladurai, F. Jian, D. Jayas, N. White, P. Fields, and A. Manickavasagan, "Feasibility of storing canola at different moisture contents in silo bags under Canadian prairie conditions," Canadian Biosystems Engineering, vol. 58, no. 1, pp. 3.9-3.20, 2016.

[15] R. Bartosik, L. Cardoso, H. A. Urcola, and R. Berruto, "Economic analysis of storing grain in silobags through a web application," in EFITA-WCCACIGR Conference "Sustainable Agriculture through ICT Innovation, pp. 24-27, Turin, Italy, 2013.

[16] L. R. A. Faroni, E. R. de Alencar, J. L. Paes, A. R. Costa, and R. C. C. Roma, "Armazenamento de soja em silos tipo bolsa," Engenharia Agricola, vol. 29, no. 1, pp. 91-100, 2009. 
[17] A. Arias Barreto, R. Abalone, A. Gastón, and R. Bartosik, "Analysis of storage conditions of a wheat silo-bag for different weather conditions by computer simulation," Biosystems Engineering, vol. 116, no. 4, pp. 497-508, 2013.

[18] A. A. Barreto, R. Abalone, and A. Gaston, "Prediction of insect development in a wheat (Triticum aestivum) silo-bag by computer simulation," in Proceedings of the 10th International Conference on Controlled Atmosphere and Fumigation in Stored Products (CAF2016), CAF Permanent Committee Secretariat, pp. 316-323, Winnipeg, Canada, 2016.

[19] R. Abalone, A. Gastón, R. Bartosik, L. Cardoso, and J. Rodríguez, "Gas concentration in the interstitial atmosphere of a wheat silobag. Part I: model development and validation," Journal of Stored Products Research, vol. 47, no. 4, pp. 268-275, 2011.

[20] R. Abalone, A. Gastón, R. Bartosik, L. Cardoso, and J. Rodríguez, "Gas concentration in the interstitial atmosphere of a wheat silo-bag. Part II: model sensitivity and effect of grain storage conditions," Journal of Stored Products Research, vol. 47, no. 4, pp. 276-283, 2011.

[21] R. Bartosik, L. Cardoso, and J. Rodríguez, "Early detection of spoiled grain stored in hermetic plastic bags (silo-bags) using CO2 monitoring," in Proceeding of 8th International Conference on Controlled Atmosphere and Fumigation in Stored Products, pp. 550-554, Sichuan Publishing House of Science and Technology, Chengdu, China, 2008.

[22] J. A. Darby and L. P. Caddick, Review of Grain Harvest Bag Technology under Australian Conditions, CSIRO Entomology, Canberra, Australia, 2007.

[23] A. W. Ridley, P. R. Burrill, C. C. Cook, and G. J. Daglish, "Phosphine fumigation of silo bags," Journal of Stored Products Research, vol. 47, no. 4, pp. 349-356, 2011.

[24] L. Cardoso, R. Bartosik, J. Rodríguez, and D. Ochandio, "Factors affecting carbon dioxide concentration in interstitial air of soybean stored in hermetic plastic bags (silo-bag)," in Proceedings of the 8th International Conference Controlled Atmospheres and Fumigation of Stored Products, pp. 565-568, Chengdu, China, 2008.

[25] R. A. Samson, E. S. Hoekstra, and C. A. N. Van Oorschot, Introduction to food-borne fungi, Centraalbureau voor Schimmelcultures, Delft, 1984.

[26] H. L. S. Tandon, Methods of Analysis of Soils, Plants, Waters, Fertilisers \& Organic Manures, Fertiliser Development and Consultation Organisation, 2005.

[27] R. Chandra, S. P. Singh, and K. Gupta, "Damping studies in fiber-reinforced composites - a review," Composite Structures, vol. 46, no. 1, pp. 41-51, 1999.

[28] H. C. Zhai, S. B. Zhang, S. X. Huang, and J. P. Cai, "Prevention of toxigenic fungal growth in stored grains by carbon dioxide detection," Food Additives \& Contaminants: Part A, vol. 32, no. 4, pp. 596-603, 2015.

[29] S. A. L. Cook, M. Professor, and D. E. Maier, Evaluation of sealed storage silos for grain fumigation, [M.S. thesis], Department of Grain Science and Industry College of agriculture, Kansas State University United States, 2016.

[30] E. Raudienè, D. Rušinskas, G. Balčiūnas, G. Juodeikienė, and D. Gailius, "Carbon dioxide respiration rates in wheat at various temperatures and moisture contents," Mapan-Journal of Metrology Society of India, vol. 32, no. 1, pp. 51-58, 2017.

[31] M. Adams and M. Moss, "Factors affecting the growth and survival of micro-organism in foods," Food Microbiology, pp. 20-62, 2008.
[32] T. S. Sayed, F. Y. Hirad, and G. H. Abro, "Resistance of different stored wheat varieties to Khapra beetle, Trogoderma granarium (Everest) and lesser grain borer, Rhizopertha Dominica (Fabricus)," Pakistan Journal of Biological Sciences, vol. 9, no. 8, pp. 1567-1571, 2006.

[33] R. F. Reitemeier, "Methods of analysis for soils, plants, and waters," Soil Science Society of America Journal, vol. 27, no. 1, pp. iv-iv, 1963.

[34] R. Gregori, P. Meriggi, A. Pietri, S. Formenti, G. Baccarini, and P. Battilani, "Dynamics of fungi and related mycotoxins during cereal storage in silo bags," Food Control, vol. 30, no. 1, pp. 280-287, 2013.

[35] P. G. Fields, "The control of stored-product insects and mites with extreme temperatures," Journal of Stored Products Research, vol. 28, no. 2, pp. 89-118, 1992.

[36] S. Beckett, B. Longstaff, and D. Evans, A Comparison of the Demography of Four Major Stored Grain Coleopteran Pest Species and Its Implications for Pest Management, CAB International, 1994.

[37] A. Bera, S. N. Sinha, N. C. Singhal, R. K. Pal, and C. Srivastava, "Studies on carbon dioxide as wheat seed protectant against storage insects and its effect on seed quality stored under ambient conditions," Seed Science and Technology, vol. 32, no. 1, pp. 159-169, 2004.

[38] T. A. MHiko, "Determination of the causes and the effects of storage conditions on the quality of silo stored wheat (Triticum aestivum) in Zimbabwe," Natural Products and Bioprospecting, vol. 2, no. 1, pp. 21-28, 2012.

[39] W. Atwell, "An overview of wheat development, cultivation, and production," Cereal Foods World, vol. 46, pp. 59-62, 2001.

[40] A. M. Buchanan and E. M. Nicholas, "Sprouting, alphaamylase and breadmaking quality," Cereal Research Communications, vol. 8, pp. 23-28, 1980.

[41] A. Miś, S. Grundas, and M. Geodecki, "Changes in hardness and thickness of wheat grain as a result of its moistening," International Agrophysics, vol. 14, pp. 203-206, 2000. 